\title{
Association of Feeding Methods and Streptococcus mutans Count with Early Childhood Caries: A Cross-sectional Study
}

\author{
${ }^{1}$ Deepa Bullappa, ${ }^{2}$ Manjunath P Puranik, ${ }^{3} \mathrm{KR}$ Sowmya, ${ }^{4} \mathrm{~T}$ Nagarathnamma
}

\begin{abstract}
Introduction: Early childhood caries (ECC) is a virulent form of dental caries that can destroy the primary dentition of toddlers and preschool children. The aim was to determine the relationship of feeding methods and oral Streptococcus mutans count in 3- to 5-year-old children with ECC.

Materials and methods: A cross-sectional study was conducted in children aged 3 to 5 years. Participating mothers were interviewed regarding child's demographic profile, educational level and socioeconomic status of parents, past medical and dental history of the mother and child, child's feeding habits, and dietary habits and oral hygiene practices of mother and child. Clinical examination for dental caries was done using the World Health Organization criteria (1997). Salivary samples of mother-child pair were collected to determine the $\mathrm{pH}$, flow rate, and $\mathrm{S}$. mutans count. Statistical tests, such as Student's t-test, analysis of variance, and Pearson's correlation were applied.
\end{abstract}

Results: Out of 150 mother-child pair, statistically significant difference in the caries experience was found between mothers and children with high and low S. mutans count. Moderate but statistically significant negative correlation was found between mean decayed, missing, and filled teeth of mothers and mean decayed, extracted and filled teeth (deft) of children with high S. mutans count. Regarding deft, there was no statistically significant difference between children who were exclusively breast fed $(7.85 \pm 2.94)$, exclusively bottle-fed $(8.67 \pm 3.98)$, and both breast and bottle-fed $(7.77 \pm 2.91)$.

Conclusion: The mean caries experience of mothers and children was $2.66 \pm 2.01$ and $7.82 \pm 2.94$ respectively, with decayed component being maximum. Moderate and significant correlation $(r=0.5$ ) was found between $S$. mutans of mothers and children in saliva. Significant negative correlation was

\footnotetext{
${ }^{1}$ Senior Lecturer, ${ }^{2,4}$ Professor and Head, ${ }^{3}$ Assistant Professor

${ }^{1}$ Department of Public Health Dentistry, Bangalore Institute of Dental Sciences, Bengaluru, Karnataka, India

${ }^{2,3}$ Department of Public Health Dentistry, Government Dental College and Research Institute, Bengaluru, Karnataka, India

${ }^{4}$ Department of Microbiology, Bangalore Medical College \& Research Institute, Bengaluru, Karnataka, India

Corresponding Author: Deepa Bullappa, Senior Lecturer Department of Public Health Dentistry, Bangalore Institute of Dental Sciences, Bengaluru, Karnataka, India, Phone: +919620512405, e-mail: deepabullappa@gmail.com
}

found between mothers and children with high $S$. mutans count $(r=-0.0284 ; p=0.046)$.

Keywords: Early childhood caries, Feeding methods, Streptococcus mutans.

How to cite this article: Bullappa D, Puranik MP, Sowmya KR, Nagarathnamma T. Association of Feeding Methods and Streptococcus mutans Count with Early Childhood Caries: A Cross-sectional Study. Int J Clin Pediatr Dent 2017;10(2):119-125.

\section{Source of support: Nil}

Conflict of interest: None

\section{INTRODUCTION}

Early childhood caries (ECC) has been a major public health problem over many years and still continues today, affecting in many ways normal growth and development as well as social adaptation of young children. Despite the recent advances in understanding the interaction of factors that may be responsible for the development of the disease, dental caries in preschool children remains a problem for the dental clinician. ${ }^{1}$

The concepts of ECC and severe ECC (S-ECC) have been used for nearly 13 years to describe caries status present in children younger than 6 years. Early childhood caries is a chronic, transmissible, infectious disease with a complex and multifactorial etiology. Factors attributed to the etiology of ECC include excessive bottle-feeding with sugar-containing liquids; breastfeeding on demand and/ or falling asleep while feeding; and nursing beyond the recommended age for weaning. Other factors associated with ECC include genetic predisposition; parental education; and nutritional, environmental, socioeconomic, and parental-style factors. $^{2}$

Although the adverse feeding patterns associated with ECC are well described, the maternal psychosocial and cultural factors underlying these behaviors that place a child at risk for ECC are unclear. ${ }^{3}$ There is considerable evidence that the bacterial species mutans streptococci (MS) are the principal microorganisms associated with ECC, and that MS are transmitted from mother to child. There is also evidence that maternal salivary levels of MS are associated with MS infection rates in their children aged 4 and 5 years. $^{1}$ 
Hence, a cross-sectional study was undertaken with the objective to assess the feeding methods and Streptococcus mutans with ECC among 3- to 5-year-old schoolchildren of Bengaluru city.

\section{MATERIALS AND METHODS}

A cross-sectional study was conducted in children aged 3 to 5 years and their mothers from January 2013 to June 2013 who can be accessed at preschools/play homes. Ethical clearance was obtained from the Institutional Ethical Committee of Government Dental College and Research Institute, Bengaluru. Necessary permission was obtained from the respective school authorities. Written informed consent was obtained from mothers of the children after explaining the study in detail.

\section{Sample Size}

Based on the previous literature, with prevalence of dental caries in mothers as 55\%, statistical power $80 \%, 95 \%$ confidence interval, $15 \%$ of marginal error, the sample size was computed as 150 . Hence, a sample size of 150 mother-child pair was considered.

\section{Sampling of Schools}

From the list of schools and play homes, schools were selected based on convenience sampling to facilitate transport of saliva samples within limited time to the Department of Microbiology laboratory, Bangalore Medical College and Research Institute (BMCRI), Bengaluru. Permission was sought from the school authorities for the study. Their cooperation was sought before finalizing the inclusion of the schools in the study and all children satisfying inclusion and exclusion criteria were considered.

\section{Inclusion Criteria}

- Children within the age group of 3 to 5 years with ECC.

- Children and mothers who are willing to participate and give their consent.

\section{Exclusion Criteria}

- Children and mothers who are medically compromised.

- Children who have lost their mothers at the time of birth.

- Children having difficulty in opening the mouth. Mothers completed a structured questionnaire survey that included family sociodemographics [age, sex, and socioeconomic status (SES)], maternal pregnancy and past medical history (mode of delivery, gestational age, birth weight), as well as child's feeding practice (breastfeeding, bottle-feeding, night-time feeding), dietary habits, and oral health practices of mothers and children. Clinical examination was carried out by a single trained and calibrated examiner under natural light using mouth mirror and community periodontal index probe, and recording was done by a trained assistant. Socioeconomic status was recorded according to Kuppuswamy's SES scale updated for January 2013., ${ }^{4,5}$

\section{Obtaining and Culturing the Salivary Samples of the Participating Mother-Child Pair}

Saliva collection was scheduled after the clinical examination. Preexisting saliva was allowed to swallow in order to clear the mouth of any residual unstimulated saliva. Mother and child were given a standard piece of paraffin wax to chew for 1 minute. Once the participants could chew comfortably on the wax, they were asked to expectorate all saliva in sterile disposable cups. The saliva collected was measured using $1 \mathrm{~mL}$ of tuberculin syringe.

The saliva samples were assessed for $\mathrm{pH}$ and flow rate; $\mathrm{pH}$ was checked using $\mathrm{pH}$ strips (coding of 2-10). Flow rate of $\leq 0.2 \mathrm{~mL} /$ minute was considered low and 0.3 to $0.7 \mathrm{~mL} /$ minute was considered as normal. ${ }^{6}$

The saliva samples were transported to the Department of Microbiology, BMCRI, Bengaluru, using thioglycolate media (transportation media) within a span of 2 hours for culturing into the prepared agar plates on the same day. Codes were given to the syringes with a permanent marker as to differentiate the samples. Before the saliva samples were cultured, the media plates were incubated at temperature of $37^{\circ} \mathrm{C}$ for 30 minutes, to remove the moisture from the plates. Serial dilutions $(1: 1,000)$ of saliva samples were done with distilled water; $0.1 \mathrm{~mL}$ of saliva was transferred to $9.9 \mathrm{~mL}$ of distilled water in sterilized test tube. The test tube was given the same code as on the syringe from which the saliva was transferred. The mixture was stirred and $0.1 \mathrm{~mL}$ of this was taken. A standard inoculation loop (4 $\mathrm{mm}$ inner diameter) was used to transfer exactly $0.1 \mathrm{~mL}$ and it was streaked on mitis salivarius bacitracin agar, selective for MS prepared according to Gold et al. ${ }^{7}$ The area on plate was divided into two halves using a glass marker and was coded with the same numbers as on the respective test tube from which the saliva was transferred. The cultured plates were immediately transferred to the carbon dioxide jar and incubated for 48 hours at $37^{\circ} \mathrm{C}$. The colonies were counted using magnifying lens and recorded as $\mathrm{N} \times 10^{4}$ colony-forming units (CFU) per $\mathrm{mL}$ of saliva. These colonies were classified into low $\left(<50 \times 10^{4} \mathrm{CFU}\right)$ and high $\left(>50 \times 10^{4} \mathrm{CFU}\right)$.

\section{Statistical Analysis}

The data collected were entered into Excel spreadsheet and analyzed using the Statistical Package for Social 
Association of Feeding Methods and Streptococcus mutans Count with Early Childhood Caries

Table 1: Distribution of the study groups (children) according to feeding practices

\begin{tabular}{lll}
\hline & $N(\%)$ & Total \\
\hline $\begin{array}{l}\text { Feeding method } \\
\text { Breastfeeding exclusively }\end{array}$ & $29(19.3)$ & $150(100)$ \\
$\begin{array}{l}\text { Bottle-feeding exclusively } \\
\text { Breastfeeding and bottle-feeding }\end{array}$ & $6(4)$ & \\
$\begin{array}{l}\text { Duration of breastfeeding } \\
\text { Birth to } 6 \text { months }\end{array}$ & $26(15.05)$ & $144(100)$ \\
$\begin{array}{l}\text { Birth to } 12 \text { months } \\
\text { Birth to } 24 \text { months }\end{array}$ & $62(43.05)$ & \\
$\begin{array}{l}\text { Birth to more than 24 months } \\
\text { Feeding practice at bedtime }\end{array}$ & $88(33.34)$ & \\
$\begin{array}{l}\text { Breastfeeding } \\
\text { Bottle containing liquids (other than }\end{array}$ & $22(14.7)$ & \\
$\begin{array}{l}\text { water) } \\
\text { Both breast- and bottle-feeding }\end{array}$ & $41(27.3)$ & \\
$\begin{array}{l}\text { Neither breast nor bottle-feeding } \\
\text { Feeding practice during night }\end{array}$ & $41(27.3)$ & \\
$\begin{array}{l}\text { Breastfeeding/bottle-containing liquid } \\
\text { other than water }\end{array}$ & $104(69.3)$ & $150(100)$ \\
$\begin{array}{l}\text { Comforting the child/a pacifier/a bottle } \\
\text { containing water }\end{array}$ & $3(2)$ & \\
$\begin{array}{l}\text { Comforting the child } \\
\text { Frequency of feeding at night }\end{array}$ & $43(28.7)$ & \\
$\begin{array}{l}\text { One or two times } \\
\text { Three to seven times }\end{array}$ & $83(79.8)$ & $104(100)$ \\
Throughout night & $2(1.9)$ & \\
\hline
\end{tabular}

Sciences version 16.0. Descriptive statistics with frequency, percentage, mean, and standard deviation were taken. Statistical significance was considered at $p<0.05$ (confidence interval of 95\%). Statistical tests, such as Student's t-test, analysis of variance, and Pearson's correlation were applied.

\section{RESULTS}

Out of 150 children, 74 (49.3\%) were males and 76 (50.7\%) were females, with the mean age of $4.33 \pm 0.79$ years, and the mean age of mothers was $29.51 \pm 2.91$ years. Majority [87 $(58 \%)$ ] of the study groups belonged to upper middle class.

Out of 150 children, 112 (74.7\%) were born vaginally and $38(25.3 \%)$ by cesarean section. More than $50 \%$ of the mothers [97 (64.67\%)] cleaned children's gum pads after feeding, wherein $54(55.67 \%)$ cleaned with damp clean cloth (Table 1).

With regard to cleaning of their child's teeth [133 $(88.7 \%)]$ mothers cleaned always; 4 (2.7\%) cleaned sometimes, and $80(53.3 \%)$ introduced cleaning at the age of 12 months. The present study showed that more than $75 \%$ were born at normal term with normal birth weight (123 [82\%]). Tables 2 and 3 show the distribution of study groups according to oral hygiene, dietary practices, and salivary characteristics respectively.
Table 2: Distribution of the study groups (mothers and children) according to the oral hygiene practices and dietary practices

\begin{tabular}{|c|c|c|}
\hline & $\begin{array}{l}\text { Mothers, } \\
N(\%)\end{array}$ & $\begin{array}{l}\text { Children, } \\
N(\%)\end{array}$ \\
\hline \multicolumn{3}{|l|}{ Oral hygiene aid used } \\
\hline Toothbrush & $150(100)$ & $142(94.7)$ \\
\hline Finger & $0(0)$ & $8(5.3)$ \\
\hline Other aids & $0(0)$ & $0(0.0)$ \\
\hline \multicolumn{3}{|l|}{ Method of cleaning } \\
\hline Vertical & $71(47.3)$ & $17(11.3)$ \\
\hline Horizontal & $62(41.3)$ & $106(70.7)$ \\
\hline Circular & $17(11.3)$ & $27(18)$ \\
\hline \multicolumn{3}{|l|}{ Material used for cleaning } \\
\hline Toothpaste & $149(99.3)$ & $149(99.3)$ \\
\hline Tooth powder & $1(0.7)$ & $1(0.7)$ \\
\hline Any other & $0(0)$ & $0(0)$ \\
\hline \multicolumn{3}{|l|}{ Frequency of cleaning } \\
\hline Once & $110(73.3)$ & $120(80)$ \\
\hline Twice & $37(24.7)$ & $28(18.7)$ \\
\hline More than twice & $3(2)$ & $2(1.3)$ \\
\hline \multicolumn{3}{|l|}{ Time of brushing } \\
\hline Before meals in the morning & $104(69.3)$ & $110(73.3)$ \\
\hline After meals at night & $3(2)$ & $8(5.3)$ \\
\hline Both times & $43(28.7)$ & $32(21.3)$ \\
\hline \multicolumn{3}{|l|}{ Frequency of sugar intake } \\
\hline Seldom or never & 0 & $4(2.7)$ \\
\hline Once a day & $20(13.3)$ & $33(22)$ \\
\hline Twice a day & $100(66.7)$ & $76(50.7)$ \\
\hline Thrice a day & $23(15.3)$ & $30(20)$ \\
\hline Four times or more & $7(4.7)$ & $7(4.6)$ \\
\hline
\end{tabular}

Table 3: Cross-tabulation of study groups according to salivary characteristics

\begin{tabular}{llll}
\hline & \multicolumn{3}{c}{$p H$ : Child } \\
\cline { 2 - 4 }$p H:$ Mother & Acidic $n(\%)$ & Neutral $n(\%)$ & Basic $n(\%)$ \\
\hline Acidic & $12(66.67)$ & $6(33.33)$ & 0 \\
Neutral & $36(28.8)$ & $89(71.2)$ & 0 \\
Basic & $1(14.3)$ & $2(28.6)$ & $4(57.1)$
\end{tabular}

Flow rate: Mother

Low $(\leq 0.2 \mathrm{~mL} /$ minute $)$

Flow rate: Child

Normal (0.3-0.7 mL/minute) $17(12.1) \quad 123(87.9)$

S. mutans: Mother

S. mutans: Child*

Low $\left(<50 \times 10^{4} \mathrm{CFU}\right) \quad 64(63.36) \quad 37(36.64)$

High $\left(>50 \times 10^{4} \mathrm{CFU}\right) \quad 5(10.2) \quad 44(89.8)$

$r=0.5,{ }^{*} p=0.00$

Statistically significant correlation was found between decayed (DT/dt), filled (FT/ft), and decayed, missing, and filled teeth (DMFT)/decayed, extracted and filled teeth (deft) of mothers and children, whereas weak and nonsignificant correlation was found for MT/et (Table 4).

Statistically significant difference was found between mean deft of children having low and high S. mutans count, whereas moderate but statistically significant negative correlation was found between mean DMFT of mothers and mean deft of children with high S. mutans count (Table 5). 
Table 4: Mean caries experience (DMFT/deft) among study groups (mother-child)

\begin{tabular}{llll}
\hline & Mothers & Children & $\begin{array}{l}\text { Correlation } \\
\text { coefficient }\end{array}$ \\
\hline $\mathrm{DT} / \mathrm{dt}$ & $1.89 \pm 1.71$ & $7.18 \pm 2.86$ & $0.32^{*}$ \\
$\mathrm{MT} / \mathrm{et}$ & $0.37 \pm 0.69$ & $0.37 \pm 0.99$ & 0.10 \\
$\mathrm{FT} / \mathrm{ft}$ & $0.41 \pm 0.69$ & $0.27 \pm 0.83$ & $0.28^{*}$ \\
$\mathrm{DMFT} /$ deft & $2.66 \pm 2.01$ & $7.82 \pm 2.94$ & $0.44^{*}$ \\
\hline
\end{tabular}

*Highly significant

Table 6: Mean caries experience among study group (children) according to $S$. mutans count and feeding practices

\begin{tabular}{|c|c|c|c|}
\hline & $\begin{array}{l}\text { Breast fed } \\
\text { (mean deft) }\end{array}$ & $\begin{array}{l}\text { Bottlefed } \\
\text { (mean deft) }\end{array}$ & $\begin{array}{l}\text { Both } \\
\text { (mean deft) }\end{array}$ \\
\hline Low S. mutans count & $6.20 \pm 1.78$ & 5 & $5.72 \pm$ \\
\hline High S. mutans count & $9.64 \pm 2.25^{a}$ & $9.4 \pm 3.975$ & $9.52 \pm 2.62^{b, c}$ \\
\hline \multicolumn{4}{|c|}{$\begin{array}{l}\text { a Significant difference between low and high } S \text {. mutans count } \\
\text { breast fed children }(p=0.001) \text {; }{ }^{\circ} \text { significant difference between } \\
\text { low and high } S \text {. mutans count both breast- and bottle-fed children } \\
(p=0.00) ;{ }^{c} \text { significant weak correlation between breast and both } \\
\text { breast- and bottle-fed children with high } S \text {. mutans count }(r= \\
0.215 ; p=0.046)\end{array}$} \\
\hline
\end{tabular}

Regarding deft, there was no statistically significant difference between children who were exclusively breast fed $(7.85 \pm 2.94)$, exclusively bottle-fed $(8.67 \pm 3.98)$, and both breast and bottle-fed $(7.77 \pm 2.91)$.

Statistically significant difference was noted for caries experience among low and high S. mutans count children who were both breast and bottle-fed and breast fed exclusively. Weak and significant correlation was found between the deft of children having high S. mutans count who were breast fed and children who were both breastand bottle-fed (Table 6).

\section{DISCUSSION}

In the present study, the age of the mothers ranged from 22 to 38 years, with the mean age being $29.51 \pm 2.91$ years, which is in line with some studies, ${ }^{8-12}$ whereas the mean age of children in the present study is $4.33 \pm 0.79$ years, which is comparable to some studies. ${ }^{13-15}$

The present study consisted of nearly equal proportion of males and females (49.3:50.7). This is in line with three studies $(49.7: 50.3),{ }^{16}(51: 49),{ }_{1}^{17}(278: 252),{ }^{18}$ whereas in some studies, there was a predominance of males over females ${ }^{8,17-30}$ and in other studies, females over males. ${ }^{31-33}$

Income was updated using All India's Average Consumer Price Index for Industrial Workers (CPI-IW) for January 2013. To modify income, the conversion factor (221) between the CPI-IW for 1998 and January 2013 was determined. ${ }^{4}$ With a total of 150 in the study group, maximum, i.e., 87 (58\%), belonged to upper middle class (II). A study conducted among Anganwadi children in Wardha, India, showed that $60.3 \%$ participants
Table 5: Mean caries experience among study groups (motherchild) according to $S$. mutans count

\begin{tabular}{lll}
\hline & $\begin{array}{l}\text { Mothers } \\
\text { (mean DMFT) }\end{array}$ & $\begin{array}{l}\text { Children } \\
\text { (Mean deft) }\end{array}$ \\
\hline Low S. mutans count & $1.74 \pm 1.30$ & $5.81 \pm 1.62$ \\
High S. mutans count & $4.55 \pm 1.89^{\mathrm{a}}$ & $9.53 \pm 2.72^{\mathrm{b}, \mathrm{c}}$ \\
\hline
\end{tabular}

${ }^{a}$ significant difference between mothers with high and low $S$. mutans count $(p=0.00)$; ${ }^{b}$ significant difference between children with high and low $S$. mutans count $(p=0.00)$; ${ }^{\circ}$ significant negative correlation between mothers and children with high $S$. mutans. S. mutans count $(r=-0.0284),(p=0.048)$

belonged to social class V; $34.5 \%$ participants belonged to social class IV. ${ }^{31}$ These results differ from the present study as there was a difference in the participants' social background.

Neonatal factors may also increase the risk for early acquisition of $S$. mutans via vertical transmission. Infants delivered by cesarean section acquire $S$. mutans earlier than vaginally delivered infants. ${ }^{34}$ In the present study, about three-fourths [112 (74.7\%)] were born by vaginal delivery, whereas one-fourth [38 (25.3\%)] was born by cesarean section. In an Indian study, $87.1 \%$ were delivered normally. In a study ${ }^{28}$ where mode of delivery was considered as a risk factor for ECC, 184 out of 350 were vaginally born.

Regarding the mode of delivery, it is in line with a study where $65.4 \%$ were born $\geq 37$ weeks of gestational period. ${ }^{28}$ Regarding birth weight, one study ${ }^{19}$ reported significant proportion of low birth weight $(36.5 \%)$ and in another study, $3.7 \%{ }^{28}$ reported $\leq 2,500 \mathrm{~g}$.

There is some debate as to whether infant formula or bovine milk in bottles and breast milk given frequently to young children contribute to the development of ECC. ${ }^{36}$ In this study, more than three-fourths of the children [115 (76.7\%)] were both bottle- and breast fed. In studies reported, breastfeeding ranged from 5 to $100 \% .{ }^{11,14,18,19,28,31,33,37-39}$ Bottle-feeding was widely prevalent in most of the studies ranging from 51 to $97.9 \%, 13,17,21,22,38,40-43$ whereas maximum mixed feeding (both breast and bottle-feeding) was found in some studies, ranging from 19 to $42.6 \%{ }^{20,27,32,35,44}$

About $50 \%$ of the mothers cleaned their child's gum pads after feeding with damp clean cloth. This is in line with a study conducted in Guntur where $71 \%{ }^{32}$ of the mothers cleaned after feeding, whereas in contrast, another study reported that $11.4 \%{ }^{33}$ cleaned after feeding. Regarding the material used to clean gum pads, the result of this study is in contrast with the study where $52 \%$ used finger to clean gum pads after feeding ${ }^{32}$ and similar to the studies $\left(11.4^{33}\right.$ and $\left.19 \%{ }^{32}\right)$ that used cotton/gauze.

Toothbrushing behavior is learned from models as part of the socialization process. Because parents play a key role in the family in transferring health-related habits to 
the children, their toothbrushing has been associated with oral cleaning frequency of their children. ${ }^{45}$ These results with regard to aidedtooth brushing are in line with the studies where proportion of aided brushing ranged from 72 to $97 \%$, $32,42,46$ while other studies have reported lesser proportion $\left(39^{18}-57.5 \%{ }^{16}\right)$ of aided brushing by mothers as fathers / caregivers were also involved in aided brushing.

Some studies have reported that children of mothers who had a dietary preference for sweets had more ECC compared with children whose mothers had a nonsweet preference. These studies suggest that a mother's personal preferences play an important role in shaping her child's dietary preference for sugar and thus can influence child's risk for ECC. ${ }^{47}$ The present study emphasized on these lines where almost equal proportion of mothers and children consumed sugar twice daily.

In this study, mother-child pairs shared similar $\mathrm{pH}$ status to a greater extent in acidic, neutral, and basic groups, more so among neutral group. Acidic-basic combination and neutral-basic combination among mother-child pairs was not observed, while 1 (14.3\%) had basic-acidic combination.

Comparing salivary flow rate, mother-child pair shared similar salivary flow rate to a greater extent in low and normal groups, more so among normal group. The ratio of finding similar flow rate to dissimilar flow rate was 4:1 and 7:1 for low and normal salivary flow rate respectively, among mother-child pair.

Out of 101 (100\%) mothers having low S. mutans count, $64(63.36 \%)$ of their children had low S. mutans count and $37(36.64 \%)$ of their children had high count. Similarly, among mothers [49 (100\%)] with high count, 5 (10.2\%) of their children had low count and $44(89.8 \%)$ of their children had high $S$. mutans count. In a study, ${ }^{10}$ in the group of mothers with high salivary $S$. mutans counts (>150 CFU), $52 \%$ of children were colonized with the bacteria. Conversely, the proportion of mothers with low S. mutans counts (1-15 CFU) was $>15 \%$.

The study showed moderate but statistically significant $(\mathrm{p}=0.048)$ negative correlation between mean DMFT of mothers $(4.55 \pm 1.89)$ and mean deft of children - (9.53 \pm 2.72 ) with high $S$. mutans count. In one study, ${ }^{48}$ higher salivary counts of $S$. mutans $\left(\geq 10^{5} \mathrm{CFU} / \mathrm{mL}\right)$ have been correlated with high dmft values $(11.5 \pm 3.2)$ and the difference was statistically significant. In another study ${ }^{49}$ having greater than $50 \mathrm{CFU}$ it was also significantly associated $(p=0.03)$ with the presence of ECC, with a higher proportion of those with greater than $50 \mathrm{CFUs}$ having ECC. A study showed a positive correlation between ECC and the levels of $S$. mutans counts $(p=0.034) .{ }^{9}$

Method of feeding is shown to be associated with rampant caries with higher prevalence occurring in children who were never breast fed. ${ }^{20}$
The present study showed no statistically significant difference among the mean scores of all three groups $(F=0.269, p=0.765)$. This is in line with the studies with regard to breastfeeding and caries where there was no statistically significant difference found. ${ }^{40}$

\section{Limitations of the Study}

The study sample comprised children attending private preschools/play-homes representing a certain class of society. Further studies may include children attending Anganwadis to have a wider representation. This study considered children with ECC for determining its association with feeding methods and S. mutans. Further studies may compare children with ECC/S-ECC and without ECC regarding feeding methods and S. mutans. The microbial culture methods employed detects growth of MS group. Hence, further studies may consider specific S. mutans media if feasible.

\section{Recommendations}

The alarming finding in this study concerning the practice of bottle-feeding in children at night points to the need to provide mothers with instructions and guidance in the feeding methods and subsequent harmful snacking patterns.

Mothers should be educated at prenatal stage about maintenance of child's oral health by cleaning the gum pads every time after feeding with damp clean cloth/ cotton/gauze.

As young children lack the ability to clean their own teeth effectively, parents should clean their children's teeth with fluoridated toothpaste at least until they reach school age.

This study showed correlation of mothers and child's S. mutans level in saliva. Hence, mothers with high levels of cariogenic bacteria must be identified and their bacterial levels should be reduced prior to infant tooth eruption in an effort to delay and/or reduce the cariogenic bacteria levels in their infants.

Mothers should be instructed to use the lift-the-lip technique to spot the white-spot lesions as first signs of dental caries.

Parents should realize that they are role models for their children. Parents' own oral health behaviors and their active role in performing oral cleaning for their children should be emphasized in dental and general health settings.

\section{CONCLUSION}

The mean caries experience of mothers and children was $2.66 \pm 2.01$ and $7.82 \pm 2.94$ respectively, with decayed 
component being maximum. Moderate and significant correlation $(\mathrm{r}=0.5)$ was found between $S$. mutans of mothers and children in saliva. Significant negative correlation was found between mothers and children with high S. mutans count $(\mathrm{r}=-0.0284 ; \mathrm{p}=0.046)$.

\section{ACKNOWLEDGMENT}

Authors would especially like to thank statistician $\mathrm{Mr}$ KP Suresh for providing all possible help in scheming up and computations.

\section{REFERENCES}

1. Vadiakas G. Case definition, aetiology and risk assessment of early childhood caries (ECC): a revisited review. Eur Arch Paediatr Dent 2008 Sep;9(3):114-125.

2. Qin M, Li J, Zhang S, Ma W. Risk factors for severe early childhood caries in children younger than 4 years old in Beijing, China. Pediatr Dent 2008 Mar-Apr;30(2):122-128.

3. Kim SW. Environmental, maternal, and child factors which contribute to early childhood caries: a unifying conceptual model. Int J Paediatr Dent 2012 May;22(3):157-168.

4. Labour Bureau, Government of India. Statistics [online]. 2013 [cited 2013Apr 30]. Available from http: / / labourbureau. nic.in/indtab.html.

5. Bairwa M, Rajput M, Sachdeva S. Modified Kuppuswamy's socioeconomic scale: Social researcher should include updated income criteria, 2012. Indian J Community Med 2013 Jul;38(3):185-186.

6. Sreebny LM, Banoczy J, Baum BJ, Edgar WM, Epstein JB, Fox PC, Larmas M. Saliva: its role in health and disease. Int Dent J 1992 Aug;42(4 Suppl 2):291-304.

7. Gold OG, Jordan HV, van Houte JA. Selective medium for Streptococcus mutans. Archs Oral Biol 1973 Nov;18(11): 1357-1364.

8. Tanaka K, Miyake Y, Sasaki S, Hirota Y. Infant feeding practices and risk of dental caries in Japan: the Osaka maternal and child health study. Pediatr Dent 2013 May-Jun;35(3): 267-271.

9. Ersin NK, Eronat N, Cogulu D, Uzel A, Aksit S. Association of maternal child characteristics as a factor in early childhood caries and salivary bacterial counts. J Dent Child (Chic) 2006 May-Aug;73(2):105-111.

10. Thorild I, Lindau-Jonson B, Twetman S. Prevalence of salivary Streptococcus mutans in mothers and in their preschool children. Int J Paediatr Dent 2002 Jan;12(1):2-7.

11. Goebel BM, Drake DR, Kramer KW, Warren JJ, Reeve J, Dawson DV. Weber-Gasparoni K. Factors associated with mutans streptococci among young WIC-enrolled children. J Public Health Dent 2012 Fall;72(4):269-278.

12. Vachirarojpisan $T$, Shinada $K$, Kawaguchi $Y$, Laungwechakan $P$, Somkote T, Detsomboonrat P. Early childhood caries in children aged 6-19 months. Community Dent Oral Epidemiol 2004 Apr;32(2):133-142.

13. Qadri G, Nourallah A, Splieth CH. Early childhood caries and feeding practices in kindergarten children. Quintessence Int 2012 Jun;43(6):503-510.

14. Azevedo TD, Bezerra AC, de Toledo OA. Feeding habits and severe early childhood caries in Brazilian preschool children. Pediatr Dent 2005 Jan-Feb;27(1):28-33.
15. Smith RE, Badner VM, Morse DE, Freeman K. Maternal risk indicators for childhood caries in an inner city population. Community Dent Oral Epidemiol 2002 Jun;30(3):176-181.

16. Hashim R, Williams S, Thomson WM. Severe early childhood caries and behavioural risk indicators among young children in Ajman, United Arab Emirates. Eur Arch Paediatr Dent 2011 Aug;12(4):205-210.

17. Chan SC, Tsai JS, King NM. Feeding and oral hygiene habits of preschool children in Hong Kong and their caregivers' dental knowledge and attitudes. Int J Paediatr Dent 2002 Sep;12(5):322-331.

18. Jose B, King NM. Early childhood caries lesions in preschool children in Kerala, India. Pediatr Dent 2003 NovDec;25(6):594-600.

19. Iida $\mathrm{H}$, Auinger P, Billings RJ, Weitzman M. Association between infant breastfeeding and early childhood caries in the United States. Pediatrics 2007 Oct;120(4):e944-e952.

20. Dini EL, Holt RD, Bedi R. Caries and its association with infant feeding and oral health-related behaviours in 3-4-yearold Brazilian children. Community Dent Oral Epidemiol 2000;28(4):241-248.

21. Tyagi $R$. The prevalence of nursing caries in Davangere preschool children and its relationship with feeding practices and socioeconomic status of the family. J Indian Soc Pedod Prev Dent 2008 Dec;26(4):153-157.

22. Sankeshwari RM, Ankola AV, Tangade PS, Hebbal MI. Feeding habits and oral hygiene practices as determinants of early childhood caries in 3 to 5 year-old children of Belgaum City, India. Oral Health Prev Dent 2012;10(3):283-290.

23. Kalra G, Bansal K, Sultan A. Prevalence of early childhood caries and assessment of its associated risk factors in preschool children of urban Gurgaon, Haryana. Indian J Dent Sci 2011 Jun;3(2):12-16.

24. van Palenstein Helderman WH, Soe W, van't Hof MA. Risk factors of early childhood caries in a Southeast Asian population. J Dent Res 2006 Jan;85(1):85-88.

25. Slabsinskiene E, Milciuviene S, Narbutaite J, Vasiliauskiene I, Andruskeviciene V, Bendoraitiene EA, Saldūnaite K. Severe early childhood caries and behavioral risk factors among 3-year-old children in Lithuania. Medicina (Kaunas)2010; 46(2):135-141.

26. Deshpande S, Dixit U, Deshpande SJ. Association between oral-health related factors and ECC in children between age 36 and 72 months from rural North Karnataka. J Indian Assoc Public Health Dent 2012;10(20):48-55.

27. Chandra MK, Jayakumar HL, Vanishree N. Prevalence of early childhood caries (Ecc) among 2-5 years old children visiting paediatric outpatient department of Government Hospitals in Bangalore city India. J Indian Assoc Public Health Dent 2010;8(15):221-226.

28. Pattanaporn K, Saraithong P, Khongkhunthian S, Aleksejuniene J, Laohapensang P, Chhun N, Chen Z, Li Y. Mode of delivery, mutans streptococci colonization, and early childhood caries in three- to five-year-old Thai children. Community Dent Oral Epidemiol 2013 Jun;41(3):212-223.

29. Agarwal V, Nagarajappa R, Keshavappa SB, Lingesha RT. Association of maternal risk factors with early childhood caries in school children of Moradabad, India. Int J Paediatr Dent 2011 Sep;21(5):382-388.

30. Masumo R, Bardsen A, Mashoto K, Åstrøm AN. Prevalence and socio behavioural influence of early childhood caries, ECC, and feeding habits among 6-36 months old children in Uganda and Tanzania. BMC Oral Health 2012 Jul 26;12:24. 
31. Gaidhane AM, Patil M, Khatib N, Zodpey S, Zahiruddin QS. Prevalence and determinant of early childhood caries among the children attending the Anganwadis of Wardha district, India. Indian J Dent Res 2013 Mar-Apr;24(2):199-205.

32. Padma M, Kumar RC, Prathap KV, Mallika P, Naidu GM. Early childhood caries and feeding habits of preschool children in Guntur city in Andhra Pradesh. J Indian Assoc Public Health Dent 2011 Oct;(18 Suppl 2):784-787.

33. Sunitha S, Chandu GN, Pushpanjali K, Jayashree SH, Shafiulla Md. Feeding habits and early childhood caries among preschool children of Davangere city, Karnataka. J Indian Assoc Public Health Dent 2006;4(7):39-42.

34. Kawashita Y, Kitamura M, Saito T. Early childhood caries. Int J Dent 2011;2011:725320.

35. Suma BS, Hiremath SS. A study of feeding habits and it's relation to early childhood caries experience in young children of 1-3 years of age in Bangalore city. J Indian Assoc Public Health Dent 2010;8(16):13-19.

36. Policy on Early Childhood Caries (ECC): Classifications, consequences, and preventive strategies. An AAPD Policy Document. Reference Manual. Oral Health Policies 2011;33(6): 47-49.

37. MohebbiSZ, VirtanenJI, Vahid-Golpayegani M, VehkalahtiMM. Feeding habits as determinants of early childhood caries in a population where prolonged a breastfeeding is the norm. Community Dent Oral Epidemiol 2008 Aug;36(4):363-369.

38. Sharma R, Prabhakar AR, Gaur A. Mutans streptococci colonization in relation to feeding practices, age and the number of teeth in 6 to 30-month-old children: an in vivo study. Int J Clin Pediatr Dent 2012 May-Aug;5(2):124-131.

39. Singh MG, Chaudhary S, Manuja N, Jabin Z. Association of feeding patterns and oral hygiene practices with early childhood caries in 3-6 year old children in Moradabad city. J Indian Assoc Public Health Dent 2010;8(15):121-125.
40. Rosenblatt A, Zarzar P. Breast-feeding and early childhood caries: an assessment among Brazilian infants. Int J Paediatr Dent 2004 Nov;14(6):439-445.

41. Hallonsten AL, Wendt LK, Mejàre I, Birkhed D, Håkansson C, Lindvall AM, Edwardsson S, Koch G. Dental caries and prolonged breast-feeding in 18-month-old Swedish children. Int J Paediatr Dent 1995 Sep;5(3):149-155.

42. Caplan LS, Erwin K, Lense E, Hicks J Jr. The potential role of breastfeeding and other factors in helping to reduce early childhood caries. J Public Health Dent 2008 Fall;68(4):238-241.

43. Nunes AM, Alves CM, Araujo FB, Ortiz TM, Ribeiro MR, Silva AA, Ribeiro CC. Association between prolonged breastfeeding and early childhood caries: a hierarchical approach. Community Dent Oral Epidemiol 2012 Dec;40(6):542-549.

44. Almushayt AS, Aly AS, Omar SE, Hind YT. Dietary and feeding habits in a sample of preschool children in Severe Early Childhood Caries (S-ECC). J King Abdulaziz Univ 2009;16(4):13-36.

45. Mohebbi SZ, Virtanen JI, Murtomaa H, Vahid-Golpayegani M, Vehkalahti MM. Mothers as facilitators of oral hygiene in early childhood. Int J Paediatr Dent 2008 Jan;18(1):48-55.

46. Ismail AI, Lim S, Sohn W, Willem JM. Determinants of early childhood caries in low-income African American young children. Pediatr Dent 2008 Jul-Aug;30(4):289-296.

47. Yoon RK, Smaldone AM, Edelstein BL. Early childhood caries screening tools: a comparison of four approaches. J Am Dent Assoc 2012 Jul;143(7):756-763.

48. Begzati A, Berisha M, Meqa K. Early childhood caries in preschool children of Kosovo- a serious public health problem. BMC Public Health 2010 Dec 24;10:788.

49. Nair R, Weber-Gasparoni K, Marshall TA, Warren JJ, Levy SM. Factors affecting early childhood caries among WIC-enrolled children in Linn County, Iowa. J Dent Child (Chic)2010 SepDec;77(3):158-165. 